\title{
Large and small
}

\section{A telltale sign of acute pontomesencephalic injury}

Figure Right pinpoint pupil and left fixed, midposition pupil with subtle outward deviation of the left eye (A), CT head with hyperdense basilar artery (arrow) (B), and diffusion-weighted images showing extensive pontine (C) and left paramedian midbrain infarcts (D)
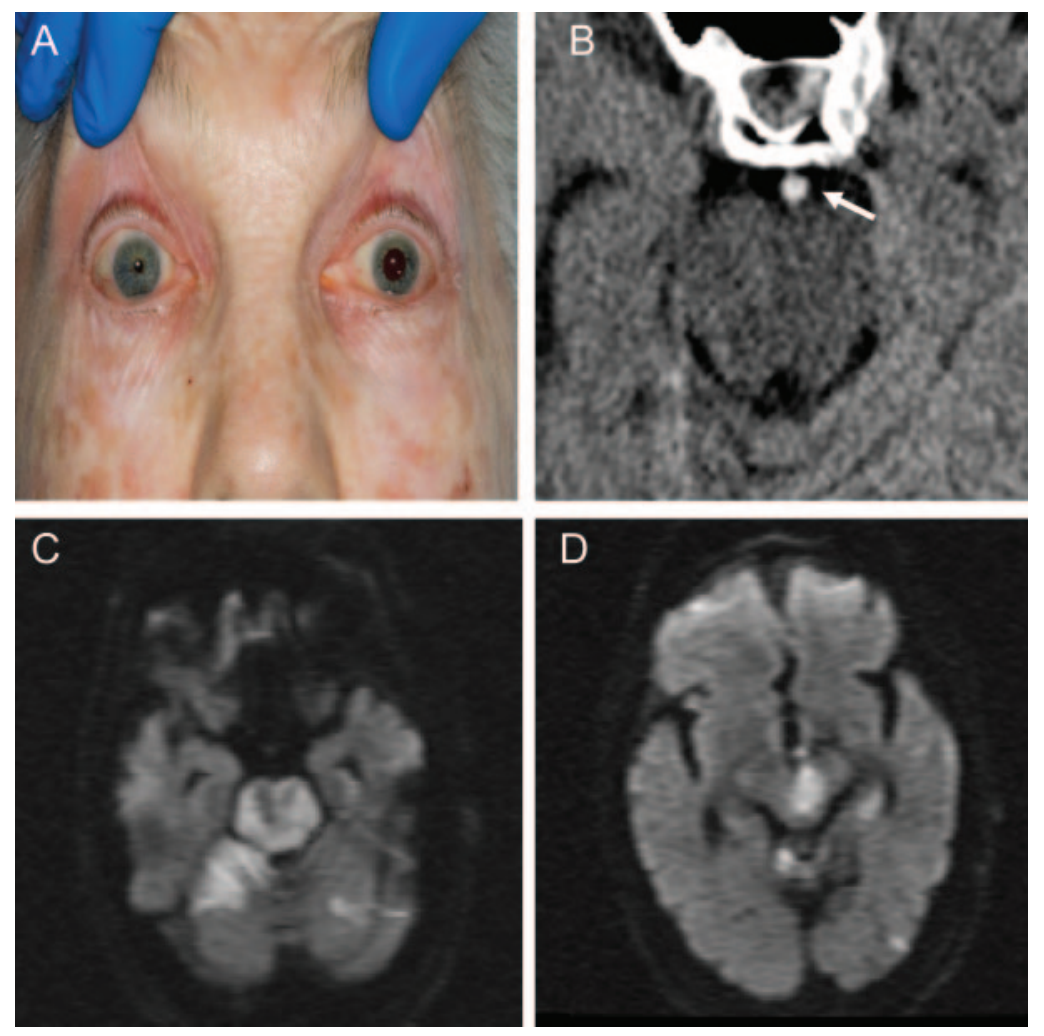

An 85-year-old woman was found comatose. Her right pupil was $2 \mathrm{~mm}$ and reactive while the left pupil was $6.5 \mathrm{~mm}$ and nonreactive (figure, A). Oculocephalic and corneal reflexes were absent, the cough reflex was preserved, and there was spontaneous bilateral decerebrate posturing.

Traditional teaching indicates that midbrain lesions cause fixed, midposition pupils while pontine lesions cause pinpoint pupils. Rarely are these findings present simultaneously in the same patient. ${ }^{1,2}$ One midposition and one pinpoint pupil in a comatose patient indicates a combined lesion of the midbrain and pons, caused in this case by an acute occlusion of the basilar artery.

Joseph D. Burns, MD, Terry K. Schiefer, MD, Eelco F.M. Wijdicks, MD, PhD, Rochester, $M N$

Disclosure: The authors report no disclosures.

Address correspondence and reprint requests to Dr. Joseph D. Burns, Mayo Clinic, Department of Neurology, 200 First Street SW, Rochester, MN 55909; burns.joseph@mayo.edu

1. Kubik CS, Adams RD. Occlusion of the basilar artery: a clinical and pathological study. Brain 1946;69:73-121.

2. Caplan LR. "Top of the basilar" syndrome. Neurology 1980;30:72-79. 


\section{Neurology}

\section{Large and small: A telltale sign of acute pontomesencephalic injury}

Joseph D. Burns, Terry K. Schiefer and Eelco F.M. Wijdicks

Neurology 2009;72;1707

DOI 10.1212/WNL.0b013e3181a56001

\section{This information is current as of May 11, 2009}

Updated Information \&

Services

References

Subspecialty Collections

Permissions \& Licensing

Reprints including high resolution figures, can be found at: http://n.neurology.org/content/72/19/1707.full

This article cites 2 articles, 1 of which you can access for free at: http://n.neurology.org/content/72/19/1707.full\#ref-list-1

This article, along with others on similar topics, appears in the following collection(s):

\section{Coma}

http://n.neurology.org/cgi/collection/coma

Infarction

http://n.neurology.org/cgi/collection/infarction

Pupils

http://n.neurology.org/cgi/collection/pupils

Information about reproducing this article in parts (figures,tables) or in its entirety can be found online at:

http://www.neurology.org/about/about_the_journal\#permissions

Information about ordering reprints can be found online:

http://n.neurology.org/subscribers/advertise

Neurology ${ }^{\circledR}$ is the official journal of the American Academy of Neurology. Published continuously since 1951, it is now a weekly with 48 issues per year. Copyright . All rights reserved. Print ISSN: 0028-3878. Online ISSN: 1526-632X.

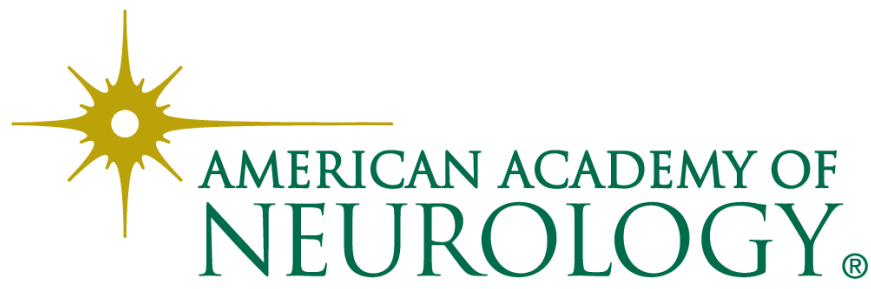

